Volume 9. Nomor 1. Januari 2014
Pandecta
http://journal.unnes.ac.id/nju/index.php/pandecta

\title{
Pelaksanaan Peraturan Daerah Nomor 7 Tahun 2011 Dalam Menunjang Pendapatan Asli Daerah dari Sektor Retribusi Parkir Kendaraan Roda Dua
}

\author{
I Gusti Ayu Purnamawati ${ }^{\bowtie}$
}

Fakultas Ekonomi dan Bisnis, Universitas Pendidikan Ganesha, Singaraja, Bali, Indonesia

Permalink/DOI http://dx.doi.org/10.15294/pandecta.v9i1.3002

\begin{tabular}{l} 
Info Artikel \\
\hline Sejarah Artikel: \\
Diterima Oktober 2013 \\
Disetujui November 2013 \\
Dipublikasikan Januari 2014 \\
\hline Keywords: \\
Levy; Vehicle Parking; Local \\
Revenue.
\end{tabular}

Abstrak

Upaya efektivitas sumber-sumber pendapatannya, dimana sumber penerimaan terbesar berasal dari sektor pajak dan retribusi daerah yang sekaligus merupakan komponen penting penerimaan kas negara dari sektor non migas. Desentralisasi dan otonomi daerah dapat digunakan sebagai salah satu jalan untuk membangun kembali negara-bangsa Indonesia serta menjadi pendorong kearah keniscayaan penyelenggaraan pemerintahan yang baik dan bersih (good governance and clean government). Penelitian ini bertujuan untuk mengetahui Fungsi, Jenis Pajak dan Penggolongannya untuk Mengukur Kontribusi Parkir Kendaraan Roda Dua di Kabupaten Buleleng, Bali. Data yang digunakan dalam penelitian ini adalah data primer dan sekunder. Teknik analisa data menggunakan analisis deskriptif kualitatif dan kuantitatif. Teknik pengumpulan data menggunakan kuesioner dan angket. Responden terdiri atas 15 aparat Pemda, dan 15 masyarakat pemilik kendaraan roda dua yang disasar kebijakan dan pelayanan. Hasil penelitian ini menunjukkan bahwa retribusi parkir kendaraan roda dua memberikan kontribusi pemasukan bagi kas daerah dalam upaya menunjang realisasi pembangunan daerah secara berkelanjutan. Target dan realisasi PAD Kabupaten Buleleng Tahun 2008 yaitu sebesar 96,76\%, mengalami penurunan pada tahun 2009 menjadi sebesar 95,53\%, Tahun 2010 (88,25\%), kemudian mengalami peningkatan yang sangat baik sehingga mencapai 104,60\% pada tahun 2011 dan $126,36 \%$ pada tahun 2012. Tingkat efektifitas parkir kendaraan roda dua di Kabupaten Buleleng pada tahun 2008 dan 2009 adalah dikategorikan efektif; tahun 2010 adalah dikategorikan cukup efektif; tahun 2011 dan 2012 adalah dikategorikan sangat efektif. Secara keseluruhan penerimaan retribusi parkir kendaraan roda dua di Kabupaten Buleleng tahun 2008-2012 menggambarkan kinerja yang baik.

\begin{abstract}
Efforts of local governments in increasing revenue is to increase the efficiency and effectiveness of their sources of income, where the greatest source of revenue comes from taxes and levies sectors which constitute an important component of the state in cash receipts from non-oil sector. Decentralization and local autonomy may be used as a way to rebuild the Indonesian nation-state as well as the necessity to drive towards good governance and clean. This study aims to determine the function, type and classification for Measuring Tax Contributions Parking Two-Wheel Vehicles in Buleleng, Bali. The data used in this study are primary and secondary data. The data analysis using qualitative and quantitative descriptive analysis. The technique of collecting data using questionnaires and questionnaires. Respondents consisted of 15 local government officials, and 15 public two-wheeled vehicle owners being targeted policies and services. The results show that an effort to support the realization of sustainable regional development. Target and actual revenue Buleleng Year 2008 in the amount of 96.76\%, a decrease in 2009 amounted to $95.53 \%$, in 2010 (88.25\%), then increased very well so as to achieve $104.60 \%$ in 2011 and $126.36 \%$ in 2012. Levels effectiveness of two-wheeler parking in Buleleng Regency in 2008 and 2009 is considered effective; 2010 is considered to be quite effective; 2011 and 2012 were categorized as very effective. Overall acceptance of a two-wheeler parking fees in Buleleng regency from 2008-2012 illustrate good performance.
\end{abstract}




\section{Pendahuluan}

Salah satu aspek konstitusional penyelenggaraan negara dan pemerintahan sejak Indonesia merdeka adalah persoalan yang berkaitan dengan penyelenggaraan otonomi sebagai subsistem negara kesatuan. Berdasarkan kenyataan-kenyataan itu tidaklah berlebihan apabila otonomi dapat dipandang sebagai salah satu sendi penyelenggaraan negara dan pemerintahan dalam perumahan Indonesia yang merdeka (Manan, 2002: 22). Seiring dengan semangat otonomi daerah yang semakin menggema, keberadaan Undang-Undang No.32 Tahun 2004 sangat esensial dan strategis untuk menjawab tingkat perkembangan aspirasi rakyat terhadap laju dinamika perkembangan Pemerintahan Daerah yang semakin kompleks yang disoroti dari berbagai dimensi permasalahan kehidupan masyarakat Daerah. Apalagi ditambah dengan posisi negara Indonesia yang multipluralis/majemuk, penyelenggaraan $\mathrm{Pe}$ merintahan Daerah sangat bervariasi karena menyesuaikan dengan laju otonomi yang dikembangkan oleh masing-masing Daerah sesuai dengan tingkat kemandirian Daerah yang bersangkutan di dalam mengatasi permasalahan yang dihadapi di lapangan.

Berdasarkan analisa Thamrin Simanjuntak sebagaimana dikutip oleh Halim (2004) mengemukakan bahwa setiap daerah di Indonesia diberikan hak untuk melakukan otonomi daerah dengan memberikan kewenangan yang luas, nyata dan bertanggung jawab yang dapat menjamin perkembangan dan pembangunan daerah. Pemberian kewenangan dimaksud dilaksanakan secara proporsional yang diwujudkan dengan pengaturan, pembagian, dan pemanfaatan sumber daya nasional yang berkeadilan, serta perimbangan keuangan pusat dan daerah. Dalam rangka perbaikan untuk peningkatan pelayanan dan kesejahteraan masyarakat, otonomi daerah merupakan sarana mewujudkan tujuan pembangunan di mana dalam pelaksanaannya diharapkan dapat bersendikan pada prinsip-prinsip demokrasi (Halim, 2004: 91). Berhubungan dengan hal tersebut, kelangsungan Undang-Undang No.32 Tahun 2004 terhadap semangat otonomi Daerah yang pada dasarnya mengemban visi dan misi agar terwujudnya kemandirian Daerah serta terwujudnya demokrasi lokal dalam kerangka upaya merealisasikan perwujudan Good Governance. Undang-Undang No.32 Tahun 2004 tentang Pemerintahan Daerah adalah sebagai konsekuensi prinsip otonomi daerah yang akan menjawab kebutuhan Daerah dari segi regulasi dan pengaturan. Menilik pelaksanaan Undang-Undang No.32 Tahun 2004, merupakan langkah bijak bagi kita untuk menelusuri mekanisme laju dinamika perjalanan penyelenggaraan Pemerintahan Daerah yang masih dalam tataran pembenahan. Pelaksanaan kebijakan Pemerintah Indonesia tentang otonomi daerah merupakan kebijakan yang dipandang sangat demokratis dan memenuhi aspek desentralisasi. Tujuan desentralisasi adalah untuk lebih meningkatkan kesejahteraan dan pelayanan kepada masyarakat, pengembangan kehidupan demokrasi, keadilan, pemerataan, serta pemeliharaan hubungan yang serasi antara pusat dan daerah, dan antar daerah serta mengurangi ketergantungan kepada Pemerintah Pusat (Maimunah, 2006: 2).

Kini desentralisasi dan otonomi daerah sebenarnya dapat digunakan sebagai salah satu jalan untuk membangun kembali negara-bangsa Indonesia. Upaya besar ini tidak cukup dilakukan hanya dengan pengelolaan isu-isu administratif belaka (kewenangan, urusan, keuangan, kepegawaian, pembinaan, pengawasan dan lain-lain), tetapi harus ditempuh dengan komitmen dan transformasi kultural yang lebih memadai. Inilah pula yang mestinya menjadi pendorong kearah keniscayaan penyelenggaraan pemerintahan yang baik dan bersih (good governance and clean government), yang di dalamnya tidak hanya terkandung makna good public governance (pemerintah) semata-mata melainkan juga good corporate governance (dunia usaha), dan civil society (masyarakat). Salah satu wujud pelaksanaan dari kebijakan desentralisasi fiskal adalah pemberian sumbersumber penerimaan bagi daerah yang dapat digali dan digunakan sendiri sesuai dengan potensinya masing-masing (Sidik, 2002).

Menurut Kaho (1997) untuk menjalankan fungsi pemerintahan daerah, maka 
faktor keuangan merupakan suatu hal yang sangat penting karena hampir tidak ada kegiatan pemerintahan yang tidak memerlukan biaya. Pemerintah tidak saja menggali sumber-sumber keuangan tetapi harus sanggup mengelola dan menggunakannya sesuai dengan prinsip value for money dalam rangka penyelenggaraan pemerintah daerah, sehingga ketergantungan terhadap bantuan pemerintah pusat harus seminimal mungkin. Dengan berkurangnya ketergantungan terhadap pemerintah pusat maka Pendapatan Asli Daerah (PAD) menjadi sumber pendapatan terbesar. Potensi pendapatan yang dimiliki setiap daerah tentu saja berbeda-beda sesuai dengan potensi sumber daya alamnya atau sumber lainnya, sehingga setiap daerah memberikan penekanan yang berbeda pula dalam setiap sumber pendapatan daerah (Astuti, 2013). Upaya yang dapat dilakukan pemerintah daerah dalam meningkatkan PAD yaitu dengan meningkatkan efisiensi dan efektivitas sumber-sumber pendapatannya, dimana sumber penerimaan terbesar berasal dari sektor pajak dan retribusi daerah yang sekaligus merupakan komponen penting penerimaan kas negara dari sektor non migas.

Kabupaten Buleleng merupakan kabupaten dengan wilayah yang paling luas di Propinsi Bali. Dengan wilayah yang cukup luas $\left( \pm 1.365 .88 \mathrm{Km}^{2}\right)$ atau $24,25 \%$ dari luas wilayah Pulau Bali, sudah seharusnya Kabupaten Buleleng mampu menambah Pendapatan Asli Daerah. Menurut Undang-undang Republik Indonesia Nomor 33 Tahun 2004 tentang Perimbangan Keuangan antara Pemerintah Pusat dan Pemerintah Daerah dalam Pasal 8 disebutkan bahwa yang menjadi sumber dari Pendapatan Asli Daerah (PAD) adalah sebagai : Hasil pajak daerah, Hasil retribusi daerah, Hasil pengelolaan kekayaan daerah yang dipecahkan, dan Lain-lain Pendapatan Asli Daerah yang sah. Pendapatan Asli Daerah (PAD) merupakan penerimaan dari pungutan pajak daerah, retribusi daerah, pengelolaan kekayaan daerah yang dipisahkan dan pendapatan lain-lain. Pajak daerah adalah pajak yang pengelolaan dan pemungutannya dilaksanakan oleh pemerintah daerah dan untuk kepentingan daerah itu sendiri (Mosal, 2013: 374). Permasalahan yang berkaitan dengan PAD adalah kewenangan perpajakan (taxing power) daerah yang sangat terbatas. Hal tersebut terlihat dari rendahnya PAD terhadap pendapatan daerah. Keadaan ini kurang mendukung akuntabilitas dari penggunaan anggaran daerah, dimana keterbatasan transfer dana dari pusat untuk membiayai kebutuhan daerah dapat ditutup oleh daerah dengan menyesuaikan tarif pajak daerahnya, sehingga hal ini dapat dilakukan dengan memperbesar taxing power di daerah (Astuti, 2013).

Pajak Daerah terdiri dari 7 (tujuh) jenis pajak daerah yang meliputi Pajak Hotel Pajak Restoran, Pajak Hiburan, Pajak Reklame, Pajak Penerangan Jalan, Pajak Pengambilan dan Pengelolaan Galian C dan Pajak Parkir. Dari ke tujuh jenis Pajak Daerah tersebut Pajak Parkir. Pajak Parkir adalah pajak yang dikenakan atas penyelenggaraan tempat parkir di luar badan jalan oleh orang pribadi atau badan, baik yang disediakan bekaitan dengan pokok usaha maupun yang disediakan sebagai suatu usaha, termasuk penyediaan tempat penitipan kendaraan bermotor dan garasi. Kendaraan bermotor yang memungut bayaran. Pajak parkir diperkirakan akan memberikan kontribusi pemasukan yang cukup berarti karena jumlah wajib pajak meliputi seluruh wilayah/daerah Kabupaten Buleleng yang menggunakan, termasuk juga dikenakan bagi wajib pajak yang berasal dari wilayah daerah lain. Selanjutnya menurut BPKD Kabupaten Buleleng melalui pungutan Pajak Parkir dikategorikan ke dalam dua bagian yakni : pajak parkir untuk kendaraan roda empat dan kendaraan roda dua.

Penelitian ini mengacu pada penelitian sebelumnya yang dilakukan oleh Wirasuta (2005). Penelitian tersebut menunjukkan tentang kontribusi pajak penerangan jalan terhadap peningkatan pendapatan asli daerah (PAD) pada Badan Pengelolaan Keuangan Daerah Kabupaten Buleleng. Kesamaan penelitian ini dengan penelitian Wirasuta (2005) yaitu sama-sama meneliti tentang pajak retribusi daerah dalam perspektif hukum Pemerintahan Daerah. Sedangkan perbedaannya terletak pada pendekatan yang digunakan dalam pembahasan dan hasil yang diperoleh, walaupun keduanya mengambil 
permasalahan Pajak Retribusi Daerah dalam perspektif hukum Pemerintahan Daerah. Wirasuta (2005) meneliti Pajak Penerangan Jalan (PPJ) dengan sudut pandang Badan Pengelolaan Keuangan Daerah sedangkan yang penulis lakukan adalah meneliti Pajak Parkir untuk kendaraan roda dua berdasarkan sudut pandang hukum Pemerintahan Daerah yakni Perda No. 07 Tahun 2011.

Penelitian ini bertujuan untuk mengetahui dan menganalisis pelaksanaan pemungutan Parkir kendaraan roda dua dan Kontribusinya terhadap peningkatan Pendapatan Asli Daerah (PAD) serta kesejahteraan masyarakat di Kabupaten Buleleng; Untuk mengetahui kendala-kendala yang dihadapi dalam pemungutan Parkir kendaraan roda dua tersebut; Untuk mengetahui langkah-langkah/ upaya yang ditempuh untuk mengatasi kendala tersebut di Kabupaten Buleleng.

\section{Metode Penelitian}

Bahan yang diperlukan dalam penelitian ini diperoleh dari penelitian kepustakaan. Bahan penelitian pustaka yaitu penelitian, yang dalam mengumpulkan data yang diperlukan untuk mengungkap kebenaran, menggunakan cara dengan membaca pustaka yang ada (Istanto, 2007 : 13). Karena penelitian ini bersifat kualitatif, maka sumber data diperoleh dari responden yang ditetapkan secara Snowball Sampling, informasi yang akan digali berusaha ditemukan lewat informan kunci/ temukan key person terkait dengan persoalan yang diangkat. Sampel atau responden dipilih berdasarkan penunjukan/rekomendasi sebelumnya. Cara ini bisa dipergunakan apabila kita ingin meneliti mengenai pendapat/ kesan dari hubungan sosial informal antara individu. Jadi, responden dari penelitian ini adalah aparatur beserta staff Pemerintah Daerah Kabupaten Buleleng pada bagian Badan Pengelolaan Keuangan Daerah (BPKD) menangani kontribusi pajak parkir kendaraan roda dua. Metode analisis data yang digunakan dalam penghitungan kinerja pajak parkir kendaraan roda dua adalah metode kuantitatif dengan data sekunder. Besarnya peningkatan efektivitas pajak parkir dapat dihitung dengan rumus (Mourin, 2013: 378):
Efektivitas $=($ Realisasi Penerimaan Pajak Parkir/ Target Penerimaan Pajak Parkir) x $100 \%$

Mahmudi (2010: 143) menyatakan bahwa efektivitas merupakan hubungan antara keluaran dengan tujuan atau sasaran yang harus dicapai. Kinerja Pemerintah Kabupaten Buleleng dalam melakukan pemungutan pajak parker kendaraan roda dua dapat dikatakan efektif apabila realisasi penerimaan pajak parkir mencapai target yang telah ditetapkan. Adapun kriteria efektivitas tersebut sesuai dengan Keputusan Menteri Dalam Negeri Nomor 690.900.327 tahun 1996 yaitu pada tabel 1 berikut:

Tabel 1. Kriteria Efektivitas Kinerja Keuangan

\begin{tabular}{lc}
\hline Tingkat Pencapaian & Kriteria \\
\hline Diatas $100 \%$ & Sangat Efektif \\
$90 \%-100 \%$ & Efektif \\
$80 \%-90 \%$ & Cukup Efektif \\
$60 \%-80 \%$ & Kurang Efektif \\
Kurang dari $60 \%$ & Tidak Efektif \\
\hline
\end{tabular}

Sumber: Depdagri, Kemendagri No. 690.900.327 tahun 1996.

\section{Hasil dan Pembahasan}

\section{a. Fungsi Pajak dalam Pembangunan Dae- rah}

Salah satu bentuk pendanaan yang dilakukan pemerintah adalah pendanaan dengan otonomi daerah yang secara resmi dimulai dari tahun 2001 sampai dengan saat ini. Spyckerelle (2001) menggambarkan perubahan tersebut dengan istilah financial follows function atau keterkaitan antara kewenangan dengan keuangan (Julastiana dan Suartana, 2014).

Kondisi geografis, budaya, tipologi ekonomi yang sangat bervariasi antar-daerah menuntut adanya strategi kebijakan yang berbeda-beda pula agar mampu mendorong akselerasi pembangunan daerah. Selaras dengan hal tersebut, otonomi daerah dan desentralisasi fiskal telah pula membuka kesempatan bagi daerah untuk mengarahkan 
kebijakan publiknya menyesuaikan dengan kebutuhan dan potensi unggulan daerah yang dimilikinya. Inovasi, kreatifitas, sensitifitas dan kejelian pemerintah daerah dalam meramu kebijakan akan menjadi kunci keberhasilan pembangunan daerah (Kementerian Keuangan RI, 2012).

Pajak daerah dan pajak nasional merupakan suatu sistem perpajakan Indonesia, yang pada dasarnya merupakan beban masyarakat sehingga perlu dijaga agar kebijakan perpajakan tersebut dapat memberikan kontribusi yang bermanfaat dan menimbulkan rasa keadilan bagi masyarakat. Sejalan dengan perpajakan nasional, maka pembinaan pajak daerah harus dilakukan secara terus menerus, terutama mengenai objek dan tarif pajaknya supaya pajak pusat dan pajak daerah tersebut saling melengkapi.

Menurut Rochmat Soemitro (1979: 23), pajak adalah: iuran rakyat kepada kas negara (Perolehan Kekayaan dari sektor partikelir ke sektor pemerintah) berdasarkan Undang-Undang (dapat dipaksakan) dengan tiada mendapat jasa imbal (Tigen Prestitie) yang langsung dapat ditunuk dan digunakan untuk membiayai pengeluaran umum (Publieke Vitgaven).

Menurut B. Usman dan K. Subroto (1980: 16), pajak adalah : pungutan yang dilakukan oleh pemerintah berdasarkan peraturan perundang-undangan, yang hasilnya dipergunakan untuk pembiayaan pengeluaran umum pemerintah, yang balasannya tidak secara langsung diberikan kepada pembayarnya, sedangkan pelaksanaannya di mana perlu dapat dipaksakan.

Menurut Saleh (2007), fungsi pajak bagi perekonomian suatu negara adalah : a. Fungsi Budgetair, yaitu fungsi pajak di dalam mengisi kas negara yang digunakan untuk membiayai pengeluaran rutin dan pembangunan, tidak merubah struktur asset dan habis untuk konsumsi, mengurangi ketimpangan, mengatasi inflansi. (Agar pemerintah dapat menjalankan tupoksinya) dan pembangunan; b. Fungsi regulerend (pengaturan), yaitu memperbaiki pendapatan yang tidak merata, merasionalkan biaya-biaya perekonomian, meningkatkan kualitas barang publik; dan c. Fungsi Stabiliner, yaitu dapat melakukan sta- bilisasi secara otomatis.

Menurut Siahaan (2009: 10) menyatakan bahwa pajak daerah merupakan pajak yang ditetapkan oleh pemerintah daerah dengan peraturan daerah (perda) yang wewenang pemungutannya dilaksanakan oleh pemerintah daerah dan hasilnya digunakan untuk membiayai pengeluaran pemerintah daerah dalam melaksanakan penyelenggaraan pemerintahan dan pembangunan di daerah. Jadi, fungsi pajak bagi perekonomian suatu negara adalah : a. untuk mengefesiensikan sumber ekonomi yang terbatas; $b$. agar konsumen menjadi rasional (rationing demand); c. dapat memperbaiki distribusi pendapatan yang tidak merata; dan d. untuk menyediakan barang-barang publik yang dapat disediakan oleh pemerintah.

Dalam setiap perekonomian pemerintah perlu melakukan berbagai jenis perbelanjaan. Pengeluaran-pengeluaran untuk membiayai administrasi pemerintah, membangun dan memperbaiki infrastruktur, menyediakan fasilitas pendidikan dan kesehatan, dan membiayai anggota polisi dan tentara untuk menjaga keamanan merpakan pengeluaran yang tidak boleh dielakkan pemerintah. Untuk dapat membiayai pengeluaran tersebut pemerintah perlu mencari dana. Dana tersebut diperoleh dari pungutan pajak ke atas rumah tangga dan perusahaan.

Secara garis besarnya berbagai jenis pajak yang dipungut pemerintah dapat dibedakan kepada dua golongan, yaitu pajak langsung dan pajak tak langsung. Pajak langsung berarti jenis pungutan pemerintah yang secara langsung dikumpulkan dari pihak yang wajib membayar pajak. Setiap individu yang bekerja dan perusahaan yang menjalankan kegiatan dan memperoleh keuntungan wajib membayar pajak. Pajak yang dipungut dan dkenakan ke atas pendapatan mereka dinamakan pajak langsung, yaitu pajak yang secara langsung dipungut dari orang yang berkewajiban untuk membayar pajak.

Sementara Pajak tak langsung adalah pajak yang bebannya dapat dipindah-pindahkan kepada pihak lain Salah satu jenis pajak tak langsung yang penting adalah pajak impor. Biasanya, pada akhirnya yang akan menanggung beban pajak tersebut adalah 
para konsumen. Yang mula-mula membayar pajak adalah perusahaan-perusahaan yang mengimpor barang. Akan tetapi, pada waktu menjual barang impor tersebut, pengimpor akan menambahkan pajak impor yang dibayarnya dalam menentukan harga penjualannya. Dengan demikian keuntungannya tidak berkurang. Pada akhirnya, para pembeli yang akan membayar pajak, yaitu dalam bentuk haga yang lebih tinggi. Contoh lain dari pajak tak langsung adalah pajak penjualan. Pajak ini biasanya ditambahkan ke harga penjualan yang ditentuakn oleh pedagang-pedagang. Oleh sebab itu pejak penjualan berkecenderungan akan mengakibatkan kenaikan harga.

Menurut Ismail (2008: 188) menyatakan bahwa pajak parkir dipungut oleh pemerintah daerah dari pengusaha pengelola perparkiran atau gedung-gedung, hotel, mal, atau lokasi lain yang mengelola parkir. Berbeda dengan uang parkir yang dibayar oleh pengendara kendaraan bermotor kepada pengelola atau penjaga parkir (digolongkan sebagai retribusi) yang pada dasarnya digunakan langsung oleh penjaga parkir untuk menjaga kendaraan yang diparkir tersebut.

Sistem Pajak yang ideal bagi suatu Negara : Harus mempunyai prinsip (Benefit Principle), yaitu memiliki asas manfaat, yang diharapkan jauh lebih besar manfaatnya dibandingkan pajak yang mereka bayarkan. Contoh : dengan membayar PBB maka pembangunan akan menjadi lebih baik; dan Pajak harus mempunyai prinsip keadilan (Equity Principle) yang dibagi lagi menjadi dua: Adil secara horizontal equity, yaitu keadilan itu harus dilihat dari basis pajak; dan Adil secara vertical equity, yaitu dilihat dari nilai pajak- nya.

Selanjutnya, pajak harus memenuhi persyaratan adanya kepastian, baik kepastian hukum maupun kepastian administrasi (administration certainty), contoh : kapan jatuh tempo pajak (When), Di mana membayar pajak (Where), Bagaimana membayar pajak (How). Apabila pajak tersebut hanya memberikan beban yang paling minimum bagi masyarakat, sehingga tidak memberatkan kehidupan ekonominya. Kemudian, harus memperhatikan administrative aspects yaitu aspek administratifnya juga perlu dipatuhi. Apabila tidak mendistorsi pasar, mengganggu keseimbangan pasar; sehingga harga barang dapat dikontrol.

\section{b. Pendapatan Asli Daerah dari Parkir Kendaraan}

Dinas Pendapatan Daerah, Dispenda Kabupaten Buleleng melakukan evaluasi pencapaian Pendapatan Asli Daerah, PAD dalam perubahan anggaran 2012 dan untuk sementara, realisasi PAD tersebut tercapai 79,60 persen. Sumber-sumber pendapatan asli daerah, PAD Kabupaten Buleleng target di tahun 2012 mencapai 116 milyar, 118 juta rupiah lebih baru terealisasi 92 milyar, 429 juta rupiah lebih sehingga sisa target yang akan dicapai sebesar 23 milyar, 688 juta rupiah lebih mampu direalisasi melalui peningkatan pemasukan pajak dan retribusi (Erawan, 2012). Dalam kaitannya dengan pajak parkir kendaraan roda dua di Kabupaten Buleleng, maka berikut ini adalah data jumlah kendaraan bermotor menurut jenis kendaraan di Kabupaten/Kota di bali Tahun 2012 (tabel 2):

Tabel 2. Banyaknya Kendaraan Bermotor Menurut Jenis Kendaraan di Empat Kabupaten/Kota di Bali Tahun 2012

\begin{tabular}{lllll}
\hline \multirow{2}{*}{$\begin{array}{l}\text { Jenis Kendaraan } \\
\text { Type of Vehicles }\end{array}$} & \multicolumn{4}{l}{ Kabupaten/Kota / Regency/City } \\
\cline { 2 - 5 } & Bangli & Karangasem & Buleleng & Denpasar \\
\hline (1) & $(2)$ & $(3)$ & $(4)$ & (5) \\
\hline $\begin{array}{l}\text { Mobil Penumpang } \\
\begin{array}{l}\text { Passenggers Cars } \\
\text { 1. Se da n / S ed an }\end{array}\end{array}$ & $\mathbf{3 1 5 1}$ & $\mathbf{5 4 6 4}$ & $\mathbf{1 2 0 5 7}$ & $\mathbf{1 4 5} 584$ \\
\hline
\end{tabular}




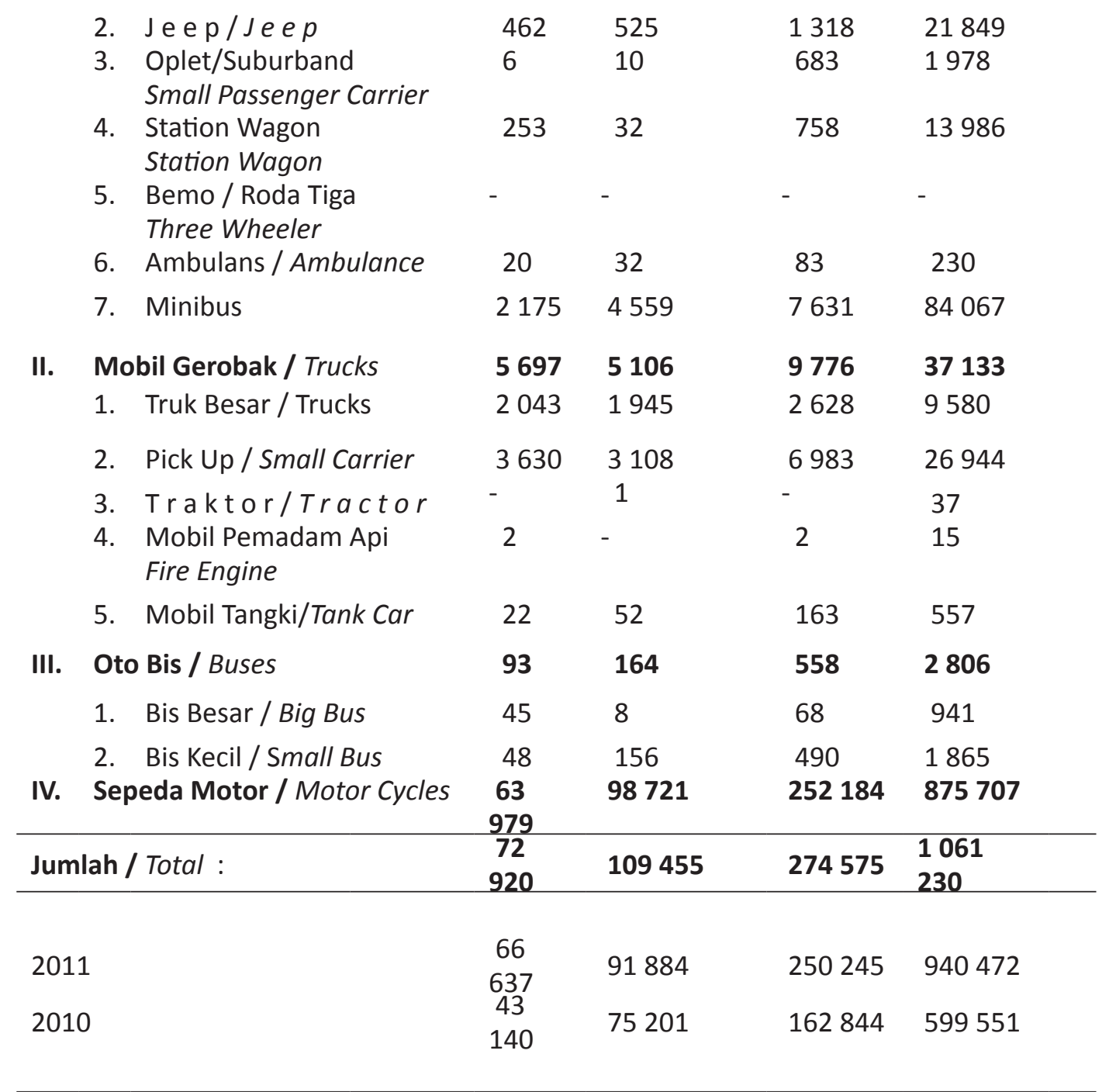

Sumber: Dinas Pendapatan Provinsi Bali, 2014.

Untuk mengetahui perkembangan penerimaan Parkir Kendaraan Roda Dua Daerah di Kabupaten Buleleng dalam 5 (lima) tahun terakhir, perlu diketahui perkembangan penerimaan antara target yang diharapkan dengan realisasi yang dicapai pada setiap tahun anggaran. Rasio Efektivitas Penerimaan pajak parkir kendaraan roda dua daerah secara keseluruhan setiap tahun anggaran dalam periode 5 (lima) tahun adalah sebagai berikut:

Tabel 3. Rasio Efektivitas Parkir Kendaraan Roda Dua Kabupaten Buleleng Tahun 2008 s/d 2012

\begin{tabular}{lc}
\hline Tahun & Rasio Efektivitas (\%) \\
\hline 2008 & 96,76
\end{tabular}

\begin{tabular}{cc}
2009 & 95,53 \\
2010 & 88,25 \\
2011 & 104,60 \\
2012 & 126,36 \\
\hline
\end{tabular}

Sumber: Data diolah dari Dinas Pendapatan Daerah Kabupaten Buleleng, 2012.

Dari tabel di atas, dapat dilihat target dan realisasi PAD Kabupaten Buleleng Tahun 2008 s/d 2012 dalam bentuk dalam bentuk prosentase (\%) rata-rata pertahun Tahun 2008 yaitu sebesar 96,76\%, mengalami penurunan pada tahun 2009 menjadi sebesar 95,53\%, Tahun 2010 (88,25\%), kemudian mengalami peningkatan yang sangat baik sehingga mencapai 104,60\% pada tahun 2011 dan $126,36 \%$ pada tahun 2012. Berdasarkan 
tingkat efektivitasnya jika hasilnya mendekati atau melebihi $100 \%$ maka pajak parkir kendaraan roda dua tersebut semakin efektif. Sehingga dapat dikatakan tingkat efektifitas pajak parkir kendaraan roda dua di Kabupaten Buleleng pada tahun 2008 dan 2009 adalah dikategorikan efektif; tahun 2010 adalah dikategorikan cukup efektif; tahun 2011 dan 2012 adalah dikategorikan sangat efektif. Secara keseluruhan penerimaan pajak parkir kendaraan roda dua di Kabupaten Buleleng tahun 2008-2012 menggambarkan kinerja yang baik.

Untuk membiayai pengeluaran berupa kondisi anggaran yang defisit, oleh pemerintah menggunakan pajak untuk pembiayaannya. Untuk melihat pembiayaan mana yang paling baik dapat diukur dari kinerja pajak yang baik apabila memiliki sifat Adequacy Ratio. Yaitu ratio kecukupan yang artinya penerimaan negara dari pajak yang diharapkan mampu dan cukup untuk membiayai pengeluaran belanja rutin dan belanja pembangunan (Tax Revenues). Bila Tax Revenues dikurangi dan pengeluaran dinaikkan, maka akan menjadi tabungan pemerintah (Government Saving). Fungsi tabungan pemerintah ini untuk membiayai pengeluaran pembangunan (belanja modal), dan bila tidak cukup akan ada defisit anggaran.

Di Daerah, bila tejadi defisit anggaran maka solusi yang diambil oleh DPRD nya dengan menjual obligasi bila BUMDnya memiliki kinerja yang bagus. Tetapi dalam kenyataannya, banyak BUMD di daerah yang jelek kinerjanya, contohnya : PDAM Bank Daerah, dan lain-lain. Ini menjadi dilematis bagi daerah.

Apabila defisit anggaran terjadi di sebuah negara, maka kebijaksanaan yang diambil oleh pemerintah adalah dengan menjual hal-hal sebagai berikut : T-Bills, yaitu sebagai pengganti Sertifikat Bank Indonesia (SBI); TBonds; SUN, yaitu Surat Utang Negara; dan Domestic Debt, yaitu pinjaman dalam negeri yang dambil dari tabungan masyarakat di bank-bank. Jadi, yang menjadi pertimbangan dari pemerintah adalah : Mencegah terjadinya distorsi, yaitu terjadinya ketidakseimbangan antara supply dan demand (permintaan); dan Menyediakan barang-barang public yang sifatnya Non Eksklusion (barang yang digunakan untuk kepentingan umum).

Adapun cara mengukur kinerja pajak adalah sebagai berikut : Ratio kecukupan: penerimaan dari pajak cukup atau tidak. Ratio kecukupan ukurannya adalah tax ratio; Penerimaan negara dari pajak dapat mudah difrediksi dengan baik; Tax ratio yang bagus apabila sebagian besar penerimaan pajaknya berasal dari income tax bukan lump-sum tax; Pajak yang baik diharapkan cukup untuk membiayai pengeluaran pemerintah; Pajak yang baik adalah pajak yang dapat diprediksi sumber pendapatannya; Kinerja pajak yang baik harus bersifat elastis; Dalam mengelola pajak harus efesien dalam pengumpulan/ biaya pungut. Harus efesien, artinya biaya pungut terhadap penerimaan harus efesien; Dalam mengelola pajak harus efektif, maksudnya penerimaan pajak harus merdeka dengan penerimaan potensinya; Pajak yang dipungut harus cocok sebagai penerimaan/ pendapatan negara dan kalau tidak cocok lebih baik dilepas; Kinerja pajak yang baik adalah harus memiliki indeks despersi yang tinggi; dan Penerimaan negara dari pajak hendaknya tidak memiliki tunggakan yang terlalu lama atau tidak boleh ada tunggakan.

Salah satu aspek penting yang harus dipenuhi adalah tersedianya dana yang memadai di daerah, sedangkan pada sisi lain dapat dimaklumi bahwa sumber-sumber keuangan daerah terutama daerah Kabupaten masih sangat terbatas, sehingga kepada daerah sangat perlu diberikan sumber bantuan pembiayaan yang cukup, akan tetapi mengingat tidak semua sumber pembiayaan dapat diberikan kepada daerah, karenanya daerah diwajibkan untuk menggali semua sumber-sumber pendapatan yang dimiliki sesuai dengan potensi daerah dan berdasarkan peraturan perundang-undangan yang berlaku. Dalam konteks pengelolaan keuangan Daerah dan konteks hukum peraturan perundang-undangan, di era otonomisasi ini dialokasikan berdasarkan pembangunan sesuai dengan Undang-Undang No.33 Tahun 2004 tentang "Perimbangan Keuangan Antara Pemerintah Pusat Dan Pemerintah Daerah". Dalam Bab V dari Undang-Undang No.33 Tahun 2004 mengatur mengenai Pendapatan Asli Daerah. 
Ketentuan lebih lanjut pada ayat (1) Pasal 6 dinyatakan bahwa PAD bersumber dari : Pajak Daerah, Retribusi Daerah, Hasil pengelolaan kekayaan Daerah yang dipisahkan; dan lain-lain PAD yang sah.

Jadi, pendanaan penyelenggaran pemerintahan agar terlaksana secara efesien dan efektif serta untuk mencegah tumpang tidih ataupun tidak tersedianya pendanaan pada suatu bidang pemerintahan, maka diatur pendanaan penyelenggaraan pemerintahan yang menjadi kewenangan daerah dibiayai dari APBD, sedangkan penyelenggaraan kewenangan pemerintahan yang menjadi tanggung jawab pemerintah dibiayai dari APBN, baik kewenangan Pusat yang didekonsentrasikan kepada Gubernur atau ditugaskan kepada Pemerinah Daerah dan/ atau Desa atau sebutan lainnya dalam rangka tugas pembantuan. Sumber-sumber pendapatan pelaksanaan Pemerintahan Daerah terdiri atas Pendapatan Asli Daerah, Dana Perimbangan, Pinjaman Daerah, dan lainlain Pendapatan Yang Sah.

Untuk menyelenggarakan otonomi daerah yang luas, nyata dan bertanggung jawab diperlukan kewenangan dan kemampuan menggali sumber keuangan sendiri, yang didukung oleh perimbangan keuangan yang melekat pada setiap kewenangan pemerintah yang menjadi kewenangan daerah. Dalam menjamin terselenggaranya otonomi daerah yang semakin mantap, maka diperlukan usaha-usaha untuk meningkatkan kemampuan keuangan sendiri yakni dengan upaya peningkatan penerimaan Pendapatan Asli Daerah (PAD) yang sudah ada maupun dengan penggalian sumber PAD yang baru sesuai dengan ketentuan yang ada serta memperhatikan kondisi dan potensi ekonomi masyarakat. Hal inilah yang menjadi salah satu kriteria penting untuk mengatasi secara nyata kemampuan daerah dalam mengatur dan mengurus rumah tangganya sendiri adalah kemampuan self supporting dalam bidang keuangan dapat dikatakan bahwa faktor keuangan merupakan faktor esensial dalam mengukur kemampuan daerah dalam melaksanakan otonominya.

Pemerintah daerah tidak akan dapat melaksanakan fungsinya dengan efektif dan efesien tanpa biaya yang cukup untuk memberikan pelayanan dan pembangunan dan keuangan inilah merupakan salah satu dasar kriteria untk mengetahui secara nyata kemampuan daerah dalam mengurus rumah tangganya sendiri (Pamuji, 1991: 124). Pemerintah khususnya pemerintah daerah sangat menyadari betapa pentingnya posisi keuangan ini dalam menyelenggarakan otonomi, begitu pula alternatif untuk mendapatkan keuangan yang memadai telah pula dipertimbangkan, maka adanya pemasukan dana dalam hal ini Pendapatan Asli Daerah (PAD) adalah sangat perlu ditingkatkan. Usahausaha dalam meningkatkan pemasukan yang bersumber dari pendapatan asli daerah sendiri akan menyebabkan semakin besar pula pendapatan daerah. Sehubungan dengan itu maka meningkatkan pendapatan daerah merupakan salah satu tugas pemerintah daerah, di mana keberhasilan tersebut tidak terlepas dari salah satu tanggung jawab Badan Pengelolaan Keuangan Daerah (BPKD) sebagai unsur pelaksana Pemerintah Daerah di bidang pendapatan Daerah.

\section{c. Pelaksanaan Peraturan Daerah}

Sumber keuangan Pemerintah Daerah berdasarkan Pasal 55 Undang-undang Nomor 5 Tahun 1974 meliputi : Pendapatan Asli Daerah (PAD) seperti pajak daerah, retribusi, penghasilan dari Dinas Daerah, Perusahaan Daerah dan sebagainya; Penghasilan dari Pemerintah Pusat seperti subsidi atau bagian pajak pusat yang diserahkan kepada daerah; dan Penghasilan lainnya yang sah seperti pinjaman, bantuan, hibah dan sebagainya.

Pemerintah Daerah boleh menciptakan sumber penghasilan melalui pajak daerah ataupun retribusi berdasarkan atas Peraturan Daerah sepanjang mendapatkan pengesahan dari instansi yang berwenang. Kepala Daerah dengan persetujuan DPRD dapat melakukan pinjaman baik dari Pemerintah Pusat maupun dari lembaga keuangan asing melalui Departemen Dalam Negeri (Wiratmojo, 2007: 17).

Sebagian besar pajak Daerah dan rertribusi Daerah pada masa lalu didasarkan pada Undang-undang Nomor 25 Tahun 1999 tentang Perimbangan Keuangan antara Pemerintah Pusat dan Pemerintah Daerah, namun 
Tabel 4. Rekapitulasi Data Kesadaran Hukum, Kepatuhan Hukum, Pelayanan Parkir Kendaraan Roda Dua dan Korelasi Kesadaran Hukum dan Kepatuhan Pembayaran Pajak Parkir

\begin{tabular}{|c|c|c|c|c|c|}
\hline No. & Para Pihak & $\begin{array}{c}\text { Kes- } \\
\text { adaran } \\
\text { Hukum }\end{array}$ & $\begin{array}{l}\text { Kepatu- } \\
\text { han } \\
\text { Hukum }\end{array}$ & $\begin{array}{l}\text { Pelayan- } \\
\text { an Parkir } \\
\text { Kendara- } \\
\text { an Roda } \\
\text { Dua }\end{array}$ & $\begin{array}{c}\text { Korelasi Kesada- } \\
\text { ran Hukum \& } \\
\text { Kepatuhan Pem- } \\
\text { bayaran Pajak }\end{array}$ \\
\hline 1. & Pemda Kab.Buleleng & 299 & 365 & 184 & 156 \\
\hline 3. & $\begin{array}{l}\text { Masyarakat Pemilik } \\
\text { Kendaraan Bermotor }\end{array}$ & 301 & 344 & 160 & 142 \\
\hline \multicolumn{2}{|c|}{ Jumlah } & 927 & 1082 & 548 & 459 \\
\hline
\end{tabular}

Sumber: Hasil Wawancara dan Observasi dengan Para Reponden di Lapangan.

dalam realita banyak sekali tugas-tugas pembantuan yang menjadi bahan pemerintah daerah masih tergantung kepada pemerintah pusat melalui dana perimbangan, maka pada tanggal 15 Oktober 2004 ditetapkanlah Undang-undang Nomor 32 Tahun 2004 tentang Pemerintah Daerah menggantikan Undang-undang Nomor 22 Tahun 1999 dan Undang-Undang No.33 Tahun 2004 tentang Perimbangan Keuangan Antara Pemerintah Pusat dan Pemerintah Daerah menggantikan Undang-Undang No.25 Tahun 1999 yang masih dirasakan mengandung muatan sentralistis pusat.

Otonomi Daerah, menurut Undangundang Nomor 32 Tahun 2004 tentang Pemerintah Daerah adalah hak, wewenang dan kewajiban daerah otonom untuk mengatur dan mengurus sendiri urusan pemerintah dan kepentingan masyarakat setempat sesuai dengan pemerintah dan kepentingan masyarakat setempat sesuai dengan peraturan perundang-undangan. Pelaksanaan Otonomi Daerah pada hakekatnya merupakan proses pembangunan Daerah dalam mencapai dan menjaga keseimbangan Daerah. Oleh karena itu, pada tiap-tiap Daerah perlu adanya distribusi dana dari Pemerintah Pusat disamping sumber dana dari Pemerintah Daerah yang bersangkutan. Demikian juga halnya pembangunan di Kabupaten Buleleng.

Kabupaten Buleleng merupakan kabupaten dengan wilayah yang paling luas di Propinsi Bali. Dengan wilayah yang cukup luas $\left( \pm 1.365 .88 \mathrm{Km}^{2}\right)$ atau $24,25 \%$ dari luas wilayah Pulau Bali, sudah seharusnya Kabu- paten Buleleng mampu menambah Pendapatan Asli Daerah. Menurut Undang-undang Republik Indonesia Nomor 33 Tahun 2004 tentang Perimbangan Keuangan antara Pemerintah Pusat dan Pemerintah Daerah dalam Pasal 8 disebutkan bahwa yang menjadi sumber dari Pendapatan Asli Daerah (PAD) adalah sebagai : a. Hasil pajak daerah; b. Hasil retribusi daerah; c. Hasil pengelolaan kekayaan daerah yang dipecahkan, dan d. Lain-lain Pendapatan Asli Daerah yang sah

Pajak Daerah terdiri dari 7 (tujuh) jenis pajak daerah yang meliputi Pajak Hotel Pajak Restoran, Pajak Hiburan, Pajak Reklame, Pajak Penerangan Jalan, Pajak Pengambilan dan Pengelolaan Galian C dan Pajak Parkir. Dari ke tujuh jenis Pajak Daerah tersebut Pajak Parkir. Pajak Parkir adalah pajak yang dikenakan atas penyelenggaraan tempat parker di luar badan jalan oleh orang pribadi atau badan, baik yang disediakan bekaitan dengan pokok usaha maupun yang disediakan sebagai suatu usaha, termasuk penyediaan tempat penitipan kendaraan bermotor dan garasi. Kendaraan bermotor yang memungut bayaran. Pajak parkir diperkirakan akan memberikan kontribusi pemasukan yang cukup berarti karena jumlah wajib pajak meliputi seluruh wilayah/daerah Kabupaten Buleleng yang menggunakan, termasuk juga dikenakan bagi wajib pajak yang berasal dari wilayah daerah lain. Selanjutnya menurut BPKD Kabupaten Buleleng melalui pungutan Pajak Parkir dikategorikan ke dalam dua bagian yakni : pajak parkir untuk kendaraan roda empat dan kendaraan roda dua. Untuk 
menghindari keluasan cakupan penelitian, di sini peneliti mengadakan pembatasan terhadap obyek pajak yang dikenakan maksudnya penelitian dispesifikkan lagi mengenai pajak parkir untuk kendaraan bermotor khususnya roda dua. BPKD menilai pajak parkir dapat menunjang pelaksanaan Otonomi Daerah yang sudah berlangsung selama ini dan telah memberikan manfaat bagi peningkatan PAD Kabupaten Buleleng terlebih lagi kepada masyarakat. Di samping keberhasilan pemerintah melaksanakan otonomi yang hasilhasilnya juga sudah terlihat, masih banyak terdapat kendala dan tantangan.

Salah satu faktor yang mempengaruhi tidak tercapainya target adalah pemahaman tentang Pajak Daerah khususnya Pajak Parkir dari para wajib pajak yang masih kurang. Wajib pajak umumnya tidak tahu apa itu pajak parkir, untuk apa dipungut pajak parkir walaupun mereka sudah membayar iuran parkir yang dikenakan dan apa yang menjadi dasar pengenaan Pajak parkir.

Pelaksanaan pajak parkir kendaraan roda dua dalam meningkatkan pedapatan asli daerah (PAD), dapat dilihat dari beberapa indikator, seperti diantaranya: kesadaran hukum, kepatuhan hukum, pelayanan parkir dan korelasi antara kesadaran hukum dan kepatuhan pembayaran pajak terhadap peningkatan PAD di Kabupaten Buleleng, SingarajaBali. Menurut hasil penelitian yang dihimpun dari beberapa responden 15 aparat Pemda, dan 15 Masyarakat pemilik kendaraan roda dua yang disasar kebijakan dan pelayanan.

Dari tabel di atas dapat dianalisa data yang diperoleh di lapangan yaitu bahwa kepatuhan hukum sudah berjalan dengan baik dengan mencapai angka 1082 hal ini diikuti dengan kesadaran hukum yang mencapai angka 927. Berdasarkan perbandingan korelasi antara kesadaran hukum dengan kepatuhan dalam hal pembayaran pajak Parkir Kendaraan Roda Dua adalah 1 : 2 yakni dengan jumlah keseluruhan 927 : 459, namun posisi pelayanan parkir masih relatif sedang karena $1: 2$ juga dengan kepatuhan hukum yang telah terlaksana (1082 : 548).

\section{Simpulan}

Berdasarkan hasil penelitian diatas maka dapat ditarik kesimpulan sebagai berikut: Pertama, Target dan realisasi PAD Kabupaten Buleleng Tahun 2008 s/d 2011 dalam bentuk dalam bentuk prosentase (\%) rata-rata pertahun Tahun 2008 yaitu sebesar $96,76 \%$, mengalami penurunan pada tahun 2009 menjadi sebesar 95,53\%, Tahun 2010 $(88,25 \%)$, kemudian mengalami peningkatan yang sangat baik sehingga mencapai 104,60\% pada tahun 2011 dan 126,36\% pada tahun 2012. Berdasarkan tingkat efektivitasnya jika hasilnya mendekati atau melebihi 100\% maka pajak parkir kendaraan roda dua tersebut semakin efektif. Sehingga dapat dikatakan tingkat efektifitas pajak parkir kendaraan roda dua di Kabupaten Buleleng pada tahun 2008 dan 2009 adalah dikategorikan efektif; tahun 2010 adalah dikategorikan cukup efektif; tahun 2011 dan 2012 adalah dikategorikan sangat efektif. Secara keseluruhan penerimaan pajak parkir kendaraan roda dua di Kabupaten Buleleng tahun 2008-2012 menggambarkan kinerja yang baik; Kedua, Kepatuhan hukum sudah berjalan dengan baik dengan mencapai angka 1082 hal ini diikuti dengan kesadaran hukum yang mencapai angka 927. Berdasarkan perbandingan korelasi antara kesadaran hukum dengan kepatuhan dalam hal pembayaran pajak Parkir Kendaraan Roda Dua adalah 1 : 2 yakni dengan jumlah keseluruhan 927 : 459, namun posisi pelayanan parkir masih relatif sedang karena 1 : 2 juga dengan kepatuhan hukum yang telah terlaksana (1082: 548).

Pajak Parkir adalah pajak yang dikenakan atas penyelenggaraan tempat parkir di luar badan jalan oleh orang pribadi atau badan, baik yang disediakan bekaitan dengan pokok usaha maupun yang disediakan sebagai suatu usaha, termasuk penyediaan tempat penitipan kendaraan bermotor dan garasi. BPKD Kabupaten Buleleng melalui pungutan Pajak Parkir dikategorikan ke dalam dua bagian yakni : pajak parkir untuk kendaraan roda empat dan kendaraan roda dua. Pajak 
parkir diperkirakan akan memberikan kontribusi pemasukan yang cukup berati karena jumlah wajib pajak meliputi seluruh wilayah/ daerah Kabupaten Buleleng.

\section{Daftar Pustaka}

Astuti, N.K.R. 2013. Dampak Pajak Daerah dan Retribusi Daerah terhadap Pendapatan Asli Daerah (PAD) di Kabupaten Gianyar. Dowload: http:// www. Google.com. Diakses tanggal 17 Mei 2014 pukul 22.12 Wita.

Badan Pusat Statistik Provinsi Bali. 2014. http://www. bps.go.id.

Dinas Pendapatan Provinsi Bali. 2014. Ringkasan Realisasi Anggaran Pendapatan dan Belanja Daerah (APBD) Kabupaten/Kota di Bali Tahun 2012.

Halim. A. 2004. Bunga Rampai Manajemen Keuangan Daerah. Jogjakarta: UPP AMP YKPN.

Julastiana, Y., dan Suartana, I. W. 2012. Analisis Efisiensi dan Efektivitas Penerimaan Pendapatan Asli Daerah Kabupaten Klungkung. Download: http://www.google.com. Diakses tanggal 17 Mei 2014 pukul 23.32 Wita.

Kementerian Keuangan Republik Indonesia, Direktorat Jenderal Perimbangan Keuangan. 2012. Tinjauan Ekonomi dan Keuangan Daerah Provinsi Bali.

Maimunah, M. 2006. Flypaper Effect pada Dana Alokasi Umum (DAU) dan Pendapatan Asli Daerah (PAD) terhadap Belanja Daerah pada Kabupat-
en/Kota di Pulau Sumatra. Simposium Nasional Akuntansi 9. Padang 23-26 Agustus.

Manan, B. 2002. Menyongsong Fajar Otonomi Daerah. Yogyakarta: , PSH FH UII.

Siahaan, M. 2009. Pajak Daerah dan Retribusi Daerah. Edisi Revisi. Jakarta: PT. Raja Grafindo Persada.

Sidik, M. 2002. Perimbangan Keuangan Pusat dan Daerah Sebagai Pelaksanaan Desentralisasi Fiskal. Makalah Seminar Setahun Implementasi Kebijakan Otonomi Daerah di Indonesia.

Soemitro, R. 1979. Dasar-Dasar Hukum Pajak dan Pajak. Jakarta: PT. Eresco

Sukirno, S. 2004. Makroekonomi Teori Pengantar Edisi Ketiga. Jakarta: PT. RajaGrafindo Persada.

Usman, B. dan K. Subroto. 1980. Pajak-Pajak Indonesia. Jakarta: Yayasan Bina Pajak.

Wiratmojo, P. 2007. Otonomi dan Pembangunan Daerah. Bali.

Undang-Undang Otonomi Daerah 2006. UndangUndang RI No.33 Tahun 2004 tentang Perimbangan Keuangan Antara Pemerintah Pusat Dan Pemerintah Daerah. Jakarta: Pressindo.

Keputusan Menteri Dalam Negeri Nomor 690.900.327 Tahun 1996 Tentang Pedoman Penilaian Kinerja Keuangan.

Peraturan Daerah Kabupaten Buleleng Nomor 07 Tahun 2011 tentang Pajak Parkir Kendaraan Roda Dua. Lembaran Daerah Tahun 2011. Tambahan Lembaran Daerah No.76. 